William \& Mary Law School

William \& Mary Law School Scholarship Repository

8-10-2020

\title{
Marginal Benefits of the Core Securities Laws
}

\author{
Kevin S. Haeberle \\ William \& Mary Law School, kshaeberle@wm.edu
}

Follow this and additional works at: https://scholarship.law.wm.edu/popular_media

Part of the Securities Law Commons

\section{Repository Citation}

Haeberle, Kevin S., "Marginal Benefits of the Core Securities Laws" (2020). Popular Media. 503.

https://scholarship.law.wm.edu/popular_media/503

Copyright c 2020 by the authors. This article is brought to you by the William \& Mary Law School Scholarship Repository.

https://scholarship.law.wm.edu/popular_media 


\section{然

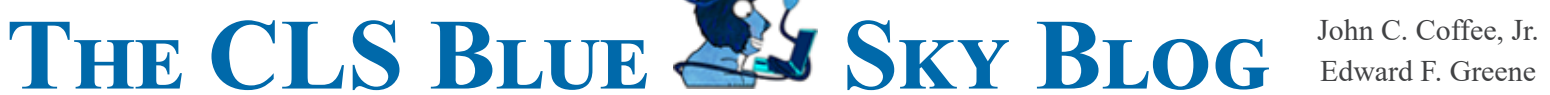

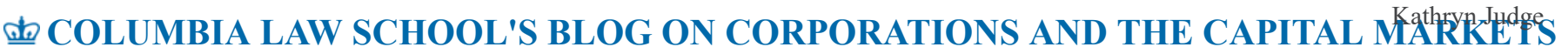

\begin{tabular}{|c|c|c|c|c|c|c|c|}
\hline $\begin{array}{c}\text { Our } \\
\text { Contributors }\end{array}$ & $\begin{array}{l}\text { Corporate } \\
\text { Governance }\end{array}$ & $\begin{array}{l}\text { Finance \& } \\
\text { Economics }\end{array}$ & $\mathbf{M} \& \mathbf{A}$ & $\begin{array}{l}\text { Securities } \\
\text { Regulation }\end{array}$ & Dodd-Frank & $\begin{array}{l}\text { International } \\
\text { Developments }\end{array}$ & $\begin{array}{c}\text { Library \& } \\
\text { Archives }\end{array}$ \\
\hline
\end{tabular}

\section{Marginal Benefits of the Core Securities Laws}

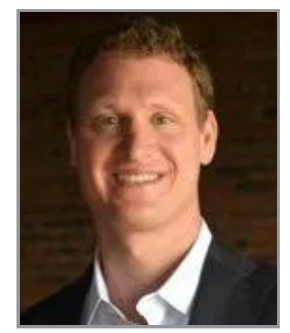

By Kevin S. Haeberle August 10, 2020

Comment

To many, the core securities laws on disclosure, fraud, and insider trading are desirable from an investor-protection perspective. But the dominant law and economics view is dubious of this thinking. Under this view, securities prices are discounted to reflect obstacles to the cash flows investors expect to receive, thereby preserving the returns those investors would expect even absent those obstacles. Information asymmetry in the stock market presents such an obstacle, and is therefore addressed by such a discount. Private ordering thus saves the day.

In Marginal Benefits of the Core Securities Laws, I aim to shed more light on this divide among policymakers, judges, and scholars. I do so by looking closely at how the reductions to information asymmetry provided by the core securities laws affect diversification-driven investors in the stock market. Strikingly, my examination reveals that these reductions provide extremely limited investor-protection benefits. For example, the most prominent manifestation of the inter-investor information asymmetry comes in the form of increased spreads between bid and ask prices - and thus higher costs for investors. These bid-ask spreads are, on average, tiny today when it comes to the vast majority of all diversification-driven investing. At the time of this post, truly diversified investors allocated 83 percent of their investment money for domestically listed stock in the stock of large-capitalization companies. [1] Strikingly, the average spread for the stock of these companies is now a mere cent, which is the legal minimum. And even that penny spread is the product of more than just information asymmetry.

On top of this not very disconcerting picture lie a number of market mechanisms that allow diversification-driven investors to escape the brunt of whatever harm these spreads and related manifestations of information asymmetry nevertheless impose. For example, all investors are now able to engage in "liquidity-making trading"- that is, in purchasing by posting their own bid quotes, and selling by posting their own ask quotes. This allows them to avoid spread costs and even gain spread benefits. In fact, the ability to engage in this type of trading is now a legal right on exchanges and a general practice on off-exchange trading platforms. And because their trading is generally far less time sensitive to that of other types of investors, diversification-driven investors are exceptionally well situated to avail themselves of the benefits of this tool. For this reason, lesser-informed investors often benefit from the presence of better-informed ones.

It follows that, even if the law and economics thinking is wrong about the largesse of price discounts, the relevant benefits of the core securities laws (i.e., those realized by diversification-driven investors thanks to lower levels of information asymmetry) are extremely limited on the margin. Of course, this conclusion and the study underlying it are solely focused on an investor-protection debate about the core securities laws and their effects in the stock market. My article does not focus on the extent to which those laws are desirable from perspectives beyond the investor-protection one introduced above. I also do not focus on the extent to which they provide important investor-protection benefits in other markets, such as the corporate bond market. And, I do not focus on the extent to which other laws (such as those regulating the market for investment advice or the structure of stock trading) provide meaningful investor-protection help.

In sum, the relevant marginal benefits of the reductions to information asymmetry provided by the core securities laws are extremely limited. These investor-protection benefits are marginal in yet another sense - even if the law and economics view on price discounts is wrong. To the extent they are motivated by a desire to protect diversification-driven investors, efforts to expand the current body of securities-specific disclosure, fraud, and insidertrading law in the name of investor protection should thus be questioned.

\section{ENDNOTE}

[1] VTI, https://www.etf.com/VTI\#fit. (numbers are as of July 17, 2020). 
This post comes to use from Professor Kevin S. Haeberle at the William and Mary Law School. It is based on his article, "Marginal Benefits of the Core Securities Laws" available here. 